\title{
MEMórias SOBRE UM CONFLITO DE TERRA EM RELATOS DE HISTÓRIA DE VIDA
}

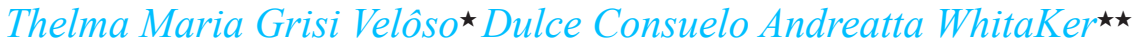

\section{Resumo}

Este artigo se propõe a analisar as memórias de pequenos produtores rurais do assentamento Camucim (litoral sul da Paraiba) sobre um conflito de terra ocorrido no final dos anos 70 e início dos anos 80, do século XX. Essas memórias foram obtidas através de entrevistas de história de vida, que foram submetidas à Análise de Discurso. A partir da história oral, pretende-se analisar o sentido subjetivo construido pelos narradores, através de suas memórias. Nesse sentido, o conflito é relembrado como uma luta legítima, abençoada por Deus, o que nos remete para o papel fundamental da Igreja nesse processo, através da Comissão Pastoral da Terra (CPT). Além disso, os narradores constroem uma imagem de lutadores corajosos e vitoriosos.

Palavras-chave: memória; conflito de terra; história de vida; análise de discurso.

\section{Memories OF A CONFLICT OVER THE OWNERSHIP OF LAND PRESENT IN LIFE HISTORY REPORTS}

\begin{abstract}
This article aims at analyzing the memories of small landowners of Camucim, a settlement in the South coast of Paraiba, over a conflict concerning the possession of a tract of land in the late 70s and early 80s of the twentieth century. These memories were gathered though Life History interviews and were submitted to Discourse Analysis. Departing from oral history we intend to analyze the subjective sense constructed by the narrators through their memories. In this sense the conflict is recollected as a legitimate struggle, blessed by God. This will lead us to the fundamental role the Church played in this process, through the Commission of the Pastoral of the Land (CPT). In addition to this, the narrators construct an image of brave, victorious fighters.

Keywords: memory; conflict over the possession of land; life history; discourse analysis.

\footnotetext{
^ Psicóloga. Possui doutorado em Sociologia pela Universidade Estadual Paulista Júlio de Mesquita Filho. E professora do Departamento de Psicologia da Universidade Estadual da Paraíba.

E-mail: thelma.veloso@ig.com.br Atualmente é professora voluntária e colaboradora, atuando na pós-graduação do Campus de Araraquara, da Universidade Estadual Paulista Júlio de Mesquita Filho. Endereço: Universidade Estadual Paulista Júlio de Mesquita Filho, Faculdade de Ciências e Letras de Araraquara. Rodovia Araraquara - Jaú, Km 1 - Campus - Araraquara, SP - Brasil. CEP: 14800-850.

E-mail: sil.onofre@uol.com.br
}

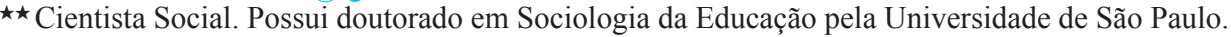




\section{INTRODUÇão}

Dentre as várias experiências de luta pela terra na Paraíba, destaca-se, no período de 1978 a 1986, a luta dos pequenos produtores rurais da Fazenda Camucim, situada no Município de Pitimbu, na microrregião do Litoral Sul do Estado da Paraíba, que faz parte da mesorregião da mata ou mesorregião canavieira.

Segundo pesquisadores do Núcleo de Documentação e Informação Histórica Regional (1992), os camponeses começaram a residir e trabalhar na Fazenda Camucim, no início do século XX, como moradores de condição. ${ }^{2}$ Em 1978, com a morte do proprietário da Fazenda, os herdeiros venderam-na para a Empresa Agroindustrial Tabu, ${ }^{3}$ cujas terras limitam-se com Camucim. Para que a empresa pudesse expandir a área cultivada com cana-de-açúcar, era necessário que os camponeses fossem retirados, origem do conflito de terra entre a Tabu e os então posseiros de Camucim.

O conflito de terra em Camucim durou oito anos e era alimentado pela forte pressão da Tabu, através de ameaças, prisões, espancamentos, sequestros, arbitrariedades de toda ordem. Por outro lado, havia a resistência desses camponeses. Apesar de algumas famílias terem "desistido" da luta, seja abandonando a área, seja aceitando as indenizações, ou ainda aceitando se transferir para outro local, uma parte significativa desses camponeses (cerca de 42 famílias) continuou lutando pela desapropriação das terras.

A Fazenda foi comprada pelo Estado, e não desapropriada, em 1986, transformando-se num Assentamento Rural administrado pelo INCRA (Instituto Nacional de Colonização e Reforma Agrária). ${ }^{4}$

Neste artigo, objetivamos trazer à reflexão, parte dos resultados de uma pesquisa realizada nesse Assentamento. Essa pesquisa teve como objetivo principal analisar as lembranças desses pequenos produtores rurais sobre as experiências de resistência e luta pela terra que vivenciaram tanto no final dos anos 70 , através da participação nesse conflito de terra com a Destilaria Tabu, quanto nos anos 60, através da participação nas Ligas Camponesas (mais especificamente na Liga de Alhandra). ${ }^{5}$ Neste artigo, pretendemos, especificamente, refletir sobre as lembranças desses pequenos produtores a respeito do conflito com a Destilaria Tabu.

Optamos pela metodologia qualitativa da História Oral e realizamos quatorze entrevistas de história de vida com os pequenos produtores. Esse tipo de entrevista "se define como um relato de um narrador sobre sua existência através do tempo, tentando reconstituir os acontecimentos que vivenciou e transmitir a experiência que adquiriu" (QUEIROZ, 1988, p. 120). Recorremos também à imagem (filmes e fotos sobre o conflito) como "detonadora" das lembranças.

A análise das lembranças fundamentou-se numa concepção de memória como processo de reconstrução. (BOSI, 1994, PORTELLI, 1999, 2000a). Ou seja, através da análise dos discursos, ${ }^{6}$ acreditamos ser possível ter acesso ao significado que essas experiências possuem hoje para quem as viveu e as reconta. O processo de rememoração parte do presente para falar do passado, e, nesse 
sentido, utiliza-se de mecanismos psicológicos e sociais. A memória é seletiva: as fantasias, os desejos e a imaginação influenciam esse processo de reconstrução. A memória é o resultado das criações e recriações dos significados; os testemunhos são uma reinterpretação subjetiva da história (PASSERINI, 1981). As fontes orais nos informam mais sobre o significado do que sobre os acontecimentos. A memória não é apenas um depositário passivo de fatos, porém, um processo ativo de criação de significações (PORTELLI, 1997, 1999).

Assim, a utilidade específica das fontes orais [...] repousa não tanto em suas habilidades de preservar o passado quanto nas muitas mudanças forjadas pela memória. Estas modificações revelam o esforço dos narradores em buscar sentido no passado e dar forma às suas vidas, e colocar a entrevista e a narração em seu contexto histórico. [...] a informação mais preciosa pode estar no que os informantes escondem e no fato que os fizeram esconder mais que no que eles contaram. (PORTELLI, 1997, p. 33, grifo do autor).

Tentaremos, portanto, enfatizar o olhar dos sujeitos em relação dialética com a História, resgatado por suas memórias sobre um momento crucial para formação da identidade do grupo - um processo dinâmico, conforme nos lembra Ciampa (1987) ao estudar o fenômeno no indivíduo. Nossos dados mostram essa dinâmica na memória coletiva em construção.

\section{O CONFLITO DE TERRA EM CAMUCIM}

As informações que seguem foram obtidas, sobretudo, a partir das consultas feitas no Arquivo Eclesiástico da Paraíba. Nessa documentação consta que, por volta de agosto/setembro de 1978, morreu o dono da fazenda Camucim. O herdeiro imediatamente comunicou aos pequenos produtores que não plantassem mais, que colhessem a lavoura e desocupassem a terra, pois pretendia criar gado. ${ }^{7}$ Quando os pequenos produtores questionaram, o proprietário começou a ameaçá-los, atirando com revólver nas portas das casas. Os pequenos produtores denunciaram o fato ao sindicato, porém o proprietário não mais apareceu. Posteriormente, surgiu o gerente da Empresa Agroindustrial Tabu, afirmando que havia comprado a fazenda e precisava da terra para plantar cana-de-açúcar. Cumpre lembrar que esses fatos ocorreram justamente no bojo das modificações resultantes do aprofundamento do capitalismo no campo, patrocinadas pelo governo através, sobretudo, da expansão canavieira estimulada pelo Programa Nacional do Álcool (PROÁLCOOL).

É importante enfatizar que o avanço e aprofundamento das relações capitalistas no campo desembocou na intensificação do processo de expropriação e expulsão do campesinato (NOVAES, 1997). As mudanças estruturais no sistema de moradia só foram possíveis a partir da intervenção do Estado na produção açucareira, através da criação da Comissão de Defesa da Produção do Álcool 
que, logo depois, seria transformada no IAA (Instituto do Açúcar e do Álcool). A modernização, incentivada pelo governo, culminou com o surgimento, em 1975, do PROÁLCOOL, que veio reforçar a política econômica instaurada nos anos 70 .

No Estado da Paraíba, especificamente, a modernização tecnológica garantiu a expansão da área cultivada sobre os tabuleiros que, até 1975, constituíam um limite ecológico, com solos pobres e arenosos, destinados à lavoura de subsistência ou cobertos pela vegetação natural. Como assinalam Moreira e Targino (1997), esse avanço da plantação de cana-de-açúcar, nas áreas da mata, nos tabuleiros e sobre as lavouras de subsistência, concorreu para impactos na economia estadual; na base técnica da produção; no emprego rural; na paisagem rural; no meio ambiente e na saúde da população.

Em síntese, no final dos anos 70, destacava-se a expansão da área cultivada com cana, o aumento da quantidade de cana produzida, como também o crescimento do número de destilarias e os impactos sociais, econômicos e ambientais. Nesse contexto, a Destilaria Tabu compra a Fazenda Camucim. Consta, na documentação pesquisada no Arquivo Eclesiástico da Paraíba, que a empresa Tabu propôs uma reunião com os pequenos produtores de Camucim, e se comprometeu a não plantar cana nas áreas ocupadas por eles. Entretanto, na semana seguinte, colocou máquinas na fazenda e começou o cultivo da cana, destruindo lavouras e fruteiras. Quando os pequenos produtores se manifestaram, foram ameaçados de prisão. Nesse período, vinte famílias "abandonaram" a fazenda, saindo sem nenhum direito, por conta das ameaças de morte, de espancamento e de prisão. Após sua saída, as casas foram incendiadas.

Restaram 56 famílias que começaram a se reunir e resolveram continuar na fazenda, lutando no judiciário pela desapropriação. Entraram, então, com um processo de manutenção de posse, que foi concedida a 33 famílias. As outras não tiveram esse direito, porque não tinham documentos. A Tabu contestou essa decisão e entrou com uma liminar de despejo. Iniciou-se, assim, o conflito de terra em Camucim, que teve a duração de oito anos.

Durante esse período, segundo a documentação pesquisada, a Tabu, várias vezes, destruiu lavouras, derrubou casas e incendiou a escola. Além disso, a ameaça era constante, posseiros foram espancados e presos, ocorrendo, inclusive, sequestros. Os capangas rondavam a área, armados de espingardas e metralhadoras. Embora a polícia tenha se instalado em Camucim, na verdade, segundo os pequenos produtores, protegia os capangas.

Entretanto, em 1985, o debate em torno da reforma agrária fortaleceu a luta dos posseiros. À época, anunciava-se que as áreas com conflito de terra seriam prioritárias para desapropriação. Nesse contexto, a Tabu recua, tornando-se mais cautelosa.

A compra da terra foi feita, em 1986, com dinheiro do próprio Estado. Segundo o INCRA, ${ }^{8}$ as terras de Camucim não foram desapropriadas, tratando-se de um contrato de compra e venda de 850 ha. Entretanto, só foram demarcados 277 ha que, hoje, correspondem à área do projeto de assentamento, distribuída para 37 famílias. 
Salientamos ainda que esse processo de luta e resistência envolveu o Estado em várias das suas instâncias, o qual, como afirmam os pequenos produtores, procurava resolver a situação da melhor forma para a Destilaria.

Por outro lado, a Igreja, através da Pastoral da Terra (atual Comissão Pastoral da Terra - CPT), destacou-se como um dos mais importantes mediadores nesse processo de luta. ${ }^{9}$ Além da Igreja, atuaram os órgãos de classe, alguns sindicatos rurais, que se caracterizam pela sua combatividade, sobretudo, o Sindicato dos Trabalhadores Rurais (STR) de Pitimbu e os centros e grupos de assessoria, como os constituídos pelos professores universitários. Os camponeses também receberam apoio de outras áreas de conflito ou assentamentos, a exemplo dos mutirões em que se arrancava a cana ou o capim plantado pela Destilaria, substituindo-o pelo plantio das culturas de subsistência.

\section{As lembranças dos Pequenos Produtores de CAMucim}

"Queria entender do medo e da coragem, e da gã que empurra a gente para fazer tantos atos, dar corpo ao suceder." (GUIMARÃES ROSA, 1986, p. 83)

Ocupar-nos-emos, a seguir, das memórias dos pequenos produtores de $\mathrm{Ca}-$ mucim sobre o conflito de terra com a Tabu. Observaremos, através dos seus discursos, como a memória vai reconstruindo os fatos vivenciados. A sua seletividade expressa tanto a subjetividade de cada um quanto a identidade coletiva veiculada pelo grupo naquela situação específica de entrevista. Nossa intenção, então, como apontado na introdução, é ir em busca dos significados que tem essa experiência de resistência e luta para os nossos narradores. Com a metodologia da análise de discurso, acabamos realizando um trabalho no qual, ora temos o discurso direto do sujeito, ora temos o discurso "indireto" - submetido à análise - o que lembra Ciampa (1987), que também captou relações entre memória e identidade - no seu caso individual - apresentando, ora a fala de Severina, ora a fala do psicólogo.

\section{A luta foi legítima}

Nos discursos, o período que separa a fase das Ligas Camponesas do conflito com a Tabu é muito curto. No entanto, Dona J. B. relembra e enfatiza que o conflito ocorreu muito tempo depois das Ligas e que o proprietário, antagonista no discurso, é quem começa a "briga":

Foi tempo que... muito tempo (enfático) depois dessa Liga Camponês foi que veio essa... essa idéia de... de... da gente brigar pela terra. [...] Os proprietário pe... pegou... pegou brigar, pegamos... pegamos dessa... dessas luta pelas terras, né? $\mathrm{Eu}$ digo a senhora, hoje a gente estamos aqui, porque houve muita união, mas se não fosse a união, não tinha ninguém aqui não (Dona J. B.). 
A transcrição leva em conta as hesitações do discurso conforme aconselham Whitaker et al (2002). Assim, o ritmo lento desvela as dificuldades da reconstrução das lembranças e ao mesmo tempo, quando deslancha, revela os significados mais intensos. O período que separa as Ligas do conflito, para alguns, pode ser curto; para outros, longo, como é o caso de Dona J. B. O que nos remete para a idéia de que no processo de rememoração, o tempo é medido subjetivamente (PORTELLI, 2000b). Por outro lado, nas lembranças da narradora, assim como na memória coletiva, foi a Tabu que entrou em atrito com os camponeses, resolvendo despejá-los, sem dar-lhes nenhum direito. Foi isso que fez com que se organizassem, e a união foi uma das características responsáveis pela vitória do movimento, como se constata a seguir:

Eu... eu... eu me lembro bem que a gente estava dentro de casa e saímos. A po... a Tabu veio aqui buscar a gente e quando acabar... na... naqueles carro grande de boi. E encheu de gente e levou. E quando chegamos lá, a conversa foi muito bonita, dizendo que... que ia tomar conta, não ia aperrear... perturbar a gente, a gente ia ficar nos cantinho e trabalhava, não ia tomar e lá vai. Também se quisesse, tinha serviço pra... pra... pra... pra... pra os pai, pra os filho [...] E quando foi no fim das conta, ele... ele tratou... quando foi com... parece com oito dia, já chegou um bocado de gente roçando já... já o lugar das capoeira da gente e lá vai. Quando foi daí a pouco, aí o povo se reuniram [...] começaram a luta. Era tudo unido. Cortando o mato e lá vai, aonde eles botava, o povo enfrentava. Até que a luta foi pra adiante, adiante. [...] (Dona J.B.).

$\mathrm{P}$ (Pesquisadora): Leocádio [o proprietário] já tinha morrido?

Já tinha morrido. Fez um contrato com a Tabu. Aí o... ele contratou, se juntou com uns homem aqui de Salinas, mandou que ele chegasse aqui e tomasse conta de... de... inventasse (enfático) que tinha comprado Camucim ou arrendado. [...] Se ele botasse o povo pra fora, Tabu compraria, e se ele não botasse... Ele inventou lá umas... umas idéia, né? Aí, inventou umas idéia de... aí se conversaram, arrendaram, tinha arrendado. Aí pra botar o povo pra fora, aí o povo não queria mais sair. (Dona J. B.)

As lembranças, na sua maioria, localizam o início da luta quando o proprietário morre, e o herdeiro decide arrendar, e não vender a propriedade. Desse modo, segundo a maioria dos narradores, o proprietário mentiu. Ele não vendeu a propriedade, mas a arrendou, com a promessa de que, quando ele colocasse os pequenos produtores para fora, a Tabu a compraria. O discurso de Dona J. B. sugere, inclusive, que o arrendamento também foi uma invenção. No entanto, além dos documentos, os líderes do movimento e o próprio advogado que acompanhou o processo confirmam a venda, e não, o arrendamento de Camucim. 
O erro, as invenções, as distorções, principalmente quando assumem caráter coletivo, tornam-se veículo de revelação do trabalho da memória e dos desejos (PORTELLI, 1989). A versão do arrendamento, em Camucim, pode ser o resultado de um trabalho da memória no qual a representação da terra, como terra de direito, e da luta, como luta de direito, leva-nos às seguintes interpretações: se a terra é deles por direito, não podia ser vendida e, portanto, não violaram o direito de ninguém; o que é reiterado em outro relato que sugere que não participou das Ligas Camponesas, porque não queria terra dos outros:

Para os camponeses, a terra é de Deus, e o homem tem acesso a ela através do trabalho - é dono da terra aquele que nela trabalha, o trabalho conduz à liberdade quando a terra é "liberta" (WOORTMANN, E.; WOORTMANN, K., 1997). Como eles trabalhavam numa terra que não tinha sido vendida, ela só podia ser deles, e eles podiam, portanto, lutar por ela, pois a terra era "liberta". Outra possibilidade de interpretação é que, inicialmente, a fazenda tenha sido arrendada ou tenha havido alguma proposta nesse sentido, e isso, mediante todas as argumentações feitas acima, foi o que ficou registrado.

Dona J. B. relembra ainda que a Tabu veio buscá-los num carro grande e os levou para a Destilaria, onde disseram que permitiriam que eles continuassem trabalhando para si nas mesmas áreas de terra e que teriam, inclusive, serviço para eles. No entanto, oito dias depois, chegaram destruindo roçados e plantando cana. Ressalta-se a construção de uma imagem negativa do proprietário, isto é, a imagem de desonesto e de mentiroso. Assim, eles reagiram porque foram atacados e, acima de tudo, porque tiveram seus direitos desrespeitados - o que legitima a luta.

As lembranças, portanto, em geral, enfatizam que lutaram por uma terra que, por direito, era deles, pois não tinha sido vendida, mas arrendada. A luta, portanto, era legítima! Atribuir ao movimento legitimidade é um dos significados que justificam e sustentam a participação no movimento.

\section{Foi UMA LUTA GRANDE, PESADA E SOFRIDA, MAS FORAM CORAJOSOS}

Os pequenos produtores relembram o processo de luta contra a Tabu como uma luta grande e pesada - "foi rocha" - como ressalta a sequência que segue:

Depois entramos nessa questão dessa terra de Chico Leocádio. Aí foi... foi... foi "rocha", foi "rocha", polícia todo dia, todo dia, todo dia, todo dia, todo dia. [...] Botamos pra arrancar cana. [...] Lá vem a polícia, mais de mil soldado. [...] Zé Francisco dizia: "Olha, olha R.... [o narrador diz o seu nome], a polícia vai te levar." "Disse": " Levar? Ele "leva uma cebola", eu meto, olhe, enxada no... na canela de um, quebro". (pausa) Quando eu cheguei foi: “Às ordem, tenente, quê que há?" Ele disse: “É que vocês estão fazendo absurdo na propriedade do homem..." "Absurdo não senhor! Nós quer é terra pra trabalhar. Não é a usina encher de cana não, nós vamos arrancar capim que seja." (pausa) Aí o... aí o tenente disse: "Faça isso não." Eu digo: "Tenente, e aonde a gente 
vamos trabalhar? A gente vamos morrer de fome? Matar a família de fome? Roubar, a gente não pode roubar que vai preso, vai ma... ser machucado. E portanto, nós quer é terra." “ Não, não precisa arrancar mais cana não." Digo: "Tanto venha!" (pausa) Agora está meus companheiro assim, e disse que eu não fui falar com o tenente. Ele só ouvia se a polícia tivesse "marretado" [...] Agora esse povo não viram quando eu cheguei [...] e os menino tudinho assim, assim sentado [...] debaixo de prisão. Quer dizer, estava ali eles todo, de sessenta ficou cinquenta e nove, tudo debaixo de prisão. (Sr. R.).

Uma das estratégias de resistência utilizadas pelos pequenos produtores de Camucim era arrancar a cana que a Tabu plantava e plantar feijão. Eram feitos, inclusive, mutirões de que participavam camponeses de outras áreas, os quais vinham a Camucim dar um apoio à luta, como já mencionado. A polícia, assim como durante as Ligas, foi o adversário imediato: era ela quem reprimia e mantinha a ordem, segundo os narradores, a favor da Destilaria. O narrador acima é enfático quando relembra esses momentos: lutavam por uma terra de trabalho e, nessa luta, assim como durante as Ligas, a presença da polícia, além de ser diária era em grande quantidade - "mais de mil soldados", o que era "rocha". A rocha é uma grande massa compacta de pedra muito dura (SILVEIRA BUENO, 1989). No discurso acima, essa dureza está associada à presença constante da polícia. Nesse sentido, o narrador conta que resistiu, defendeu-se e enfrentou a polícia.

Além da imagem de uma pessoa corajosa, destemida e temida, as lembranças do Sr. R. trazem à tona a cobrança dos outros companheiros que duvidam da sua coragem para se impor, confrontar-se, desobedecer - reiterando as lembranças, presentes também em outras entrevistas, de que havia uma pressão social para participarem do conflito. O narrador acrescenta que eles só teriam percebido que ele enfrentara a polícia se ele tivesse sofrido uma agressão física - o que nos reporta, como em outras entrevistas, ao sofrimento como prova da participação. Por outro lado, observemos que, dos 60 camponeses, foram presos 59, o que sugere que o Sr. R. foi o único que não foi preso.

As lembranças do Sr. R. são sempre marcadas por esse enfrentamento, e a imagem que constrói de si é de alguém que tem coragem de se confrontar com a polícia, é ousado, não é submisso nem passivo. Chega, em alguns momentos, a ser agressivo, o que é contrário à imagem de subserviência que faz parte do estereótipo camponês. A imagem que o Sr. R. constrói, através de suas lembranças, é, portanto, daquele que enfrenta e não sofre punições, é destemido e temido, revertendo a situação em favor dos camponeses, o que nos remete à idealização da auto-imagem cultivada pela memória. No entanto, em outra situação, relembra quando apanhou da polícia a ponto de ser hospitalizado. Mas, como ele mesmo afirma, "apanhou e deu”. E o tenente que o prendeu foi punido, já morreu.

Esse tipo de postura (o enfrentamento) é constatado noutros discursos e nos leva a supor que a imagem que querem veicular é a de pessoas que foram capazes de questionar o poder, um poder que, historicamente, oprimiu-os e ain- 
da os oprime. Além da imagem de temido, destemido e corajoso, o discurso do Sr. R., ao afirmar que os que são contra eles sempre são punidos, sugere que ele detém mais que uma força física.

Nas memórias dos narradores, a luta foi uma verdadeira "guerra", e, nesse processo, eles foram lutadores, organizados, inteligentes, corajosos, unidos e solidários - o que compõe hoje o processo dinâmico da identidade do grupo.

Para o Sr. Z. G., que foi um dos líderes do movimento, a luta também é considerada como pesada, devido à repressão sofrida e, dentre aquilo que considera como repressão, relembra que o Sr. R. apanhou da polícia:

Cheguei aqui em 69 [...] Passamos mais ou menos aqui uns três ano. [...] o... patrão daqui morre [....] Aí a família vende a propriedade a Tabu, aí entrou em atrito com a gente, pra gente ser despejado, sem direito a nada. Aí foi por isso que a gente se organizamos e... e foi uma grande luta, luta pesada aqui. (pausa) Com todo mundo. Nesse tempo, tinha setenta... setenta morador, mas o que acontece que muito foram embora com a repressão do... do proprietário. Agora a repressão era de vários jeito: era com os pessoal do SNI e (pausa) com dinheiro, [...] com capanga, polícia, (pausa) governo [...] mandando fazer repressão também e foi por isso que a gente decidimos um tempo a ir se acampar na praça, que a repressão era... era... era grande. Entramos em atrito com a polícia e [...] teve um companheiro que quebraram a coste... as costelas dele, R....[diz o nome] [...] Isso tudo foi a repressão da Usina. (pausa) Mas também a repressão era daquelas pessoas que era mais... que era mais líder com o... com o movimento, a repressão era mais em cima dele. Eu mesmo, vários dia, eu sempre que viajava... vários dia, quando chegava em casa, ia chegando em casa a re... os capanga vinha... vinha atrás, vinha até nesse pé de jaca aí. Eu morava aqui embaixo, vários dia, várias noite, até que chegou o tempo que ainda de dia mesmo ele andava "atocalhando", "mode" vê que me pegava (funga) (pausa). Mas também foi como a gente ganhamos a terra, com a luta do pessoal, o pessoal junto (pausa) e várias casa queimada, mas foi bom até que... que não morreu ninguém, andou perto, (pausa) [...] mas não deu, não deu pra morrer gente não. (pausa) Não foi como em... em outros canto [...] a organização era mais pouca [...] por isso que morre, que morre, morreu várias pessoas. E a gente aqui era mais... era mais organizado. Tudo que a gente queria fazer era junto. (pausa) Tinha a repressão, mas a gente estava junto, [...] mas... como em 64, no tempo da Liga Camponesa, morreu muito, morreu muito companheiro, mas diz quando um está morrendo é pra dar a vida a outro (Sr. Z. G.; grifo nosso). 
Nessa sequência discursiva, também a morte do proprietário marca a venda da fazenda à Tabu. Para o Sr. Z. G., a fazenda foi vendida. Ele não menciona que ela tenha sido arrendada. A luta foi pesada por conta da repressão que era grande - termo verbalizado oito vezes na sequência acima - tanto do Serviço Nacional de Informação (SNI) quanto dos capangas, da polícia e do governo. Não podemos desconsiderar que estavam em plena ditadura militar. Sr. Z. G. relembra também que a repressão era maior em relação aos líderes e nos dá a entender que era um deles.

Ao relatarem suas lembranças sobre o conflito com a Tabu, alguns momentos vivenciados durante os, aproximadamente, oito anos de luta (elucidados anteriormente) são relembrados pelos entrevistados. Entre esses momentos, estão os espancamentos, a destruição da escola e das casas, o acampamento debaixo das mangueiras em Camucim e o acampamento na Praça João Pessoa (na capital paraibana). Observamos também o cuidado em relatar estratégias de luta que não os comprometessem e de exaltarem a presença da Igreja. Importante lembrar mais uma vez que o conflito ocorreu em plena ditadura militar, que foram vítimas de muita repressão e que, por isso, veiculam uma imagem que ainda conserva muitos acontecimentos sob sigilo. Sendo assim, no processo de rememoração, deparamo-nos também com as censuras e os silêncios. Essa postura também se evidencia no discurso daqueles que passaram por experiências mais marcantes, como é o caso dos que foram espancados durante o processo de luta.

O Sr. Z. G., por exemplo, relembra que os capangas o perseguiam, porém não relata que eles o pegaram e que foi espancado. Observemos que as hesitações no discurso dele, e, inclusive, o fungar, remetem-nos para aquelas experiências que não podem ser lembradas, que são censuradas, mas que não são esquecidas. As bruscas e as inesperadas interrupções, assim como os silêncios, são recursos empregados diante da dor e da vergonha de relatar algo (POLLAK, 1989).

O Sr. Z. G. orienta seu discurso para o fato de ter sido só assim, através das experiências de pressão e repressão, que ganharam a terra. Por serem unidos, organizados, explica-se o fato de não ter morrido ninguém. O seu discurso deixa claro também que, "quando um está morrendo, é para dar a vida a outro", o que expressa consciência histórica, à medida que, ao evidenciar a própria subjetividade, compreende o movimento objetivo da história.

Dentre as características inerentes à imagem de si, que os narradores constroem através das lembranças, outra que se destaca é a de sofredores. Nesse sentido, Dona B., em um trecho de sua entrevista, afirma que ganharam a terra - foram vitoriosos - agradecendo, repetidamente, a Deus por isso e expressando enfaticamente que sofreram e lutaram muito. Assim, reitera o sofrimento como critério de participação.

Sofremos muito. Agora hoje, graças a Deus, graças a Deus, graças a Deus, eu dou muita bênção a Jesus Cristo porque nós estamos no céu. Estamos no que é da gente. Lutamos, ganhamos a terra, ganhamos casa, temos tudo o que a gente queria, né? Eu dou muito graças a Deus. A Jesus, agradeço muito pelo que Jesus fez por nós, mas nós sofremos, 
sofremos e muito (enfático), não foi pouco não. Menino meu [...] Quando ele via uma zoada de carro [...] ia bater no Barranco, na casa da minha mãe, a avó dele, com medo. Aí passava dois, três dia, oito. [...] Lutamos muito (Dona B.)

As lembranças, em geral, enfatizam a reação dos camponeses contra as atrocidades cometidas pela polícia. Inúmeras vezes, a reconstrução da escola é o cenário para esse enfrentamento, em que a presença dos mediadores também é ressaltada como aqueles que alertaram e contiveram o impulso dos pequenos produtores de agredirem a polícia.

Nesse sentido, quando relembram as prisões durante o conflito, estas são imediatamente associadas à liberdade proporcionada pelo doutor - o advogado estava sempre presente para defendê-los e libertá-los. Essa proteção, além da proteção divina, aparece, nos discursos, como mais um elemento que lhes facilita enfrentar a polícia e sair-se bem das situações. A polícia, antagonista no discurso, tem receio da força e da organização.

Assim, relembram que reagiam, e essa reação é mais enfatizada por uns do que por outros. Em geral, os narradores ressaltam que não tiveram medo. Por outro lado, o termo "sofrimento" é reiterado muitas vezes nas suas falas, para caracterizar o período difícil que vivenciaram com ameaças, prisões, espancamentos, intimidações etc. Não podiam ter medo, pois, se saíssem de lá, só lhes restaria a delinquência. As lembranças convergem para a ideia de que a coragem foi imprescindível para a luta e também para a construção da identidade do grupo.

Mas tem uma coisa, minha filha, a gente venceu essa luta todinha com força, coragem, amor a Deus. (pausado) É. (Dona L.)

Chama à atenção o fato de afirmarem que aqueles que aceitaram as indenizações da Tabu ou perderam tudo ou morreram. Pode-se pensar que o medo de perder a terra foi maior do que o medo de perder a vida, já que, sem a terra, não existe vida, pois a terra é "a morada da vida". Se terra é vida, então vale a pena morrer por ela.

A terra é um espaço essencial para a construção da identidade dos camponeses - sem a terra, o camponês não é ninguém. Como afirma Scott (1981), quanto mais a subsistência dos camponeses estiver em risco - o direito à sobrevivência, como princípio moral que regula a vida dos camponeses - mais eles estão dispostos a se arriscar por ela e maior será a necessidade de repressão para vencer a sua resistência.

É interessante perceber que, nas lembranças dos entrevistados, o medo tanto foi responsável pela permanência na luta quanto pela desistência dela. Assim, os que permaneceram tinham medo de morrer de fome, de ir morar nas favelas. Os que desistiram, por sua vez, também tinham medo da morte, de enfrentar o poder, de não vencer, de perder "a terra de trabalho", e lutaram por novas formas de vida fora de Camucim. Segundo Anni et al. (1990), o medo e a coragem podem ser vistos como duas faces da mesma moeda, por isso não podem ser considerados como aspectos contrapostos. Os autores citados, baseados em entrevistas com mulheres italianas que participaram do movimento de Resistência ao Fascismo, afirmam que o fato de ter medo faz com que se ame de tal modo a vida que leva as pes- 
soas a procurarem novas formas de vida. Segundo os referidos autores, o medo é sempre uma emoção funcional em relação à sobrevivência, e todas as expressões (insegurança, desespero, depressão etc.) daí decorrentes são reflexos do mesmo sentimento, isto é, o medo da morte. São, portanto, a expressão do instinto da vida. Os autores recorrem à Gestalt para explicar que esses instintos estão presentes em todas as pessoas e as levam a procurar o risco, mas também, a segurança.

As lembranças, portanto, são marcadas pela coragem que tiveram de continuar lutando. Sobre esse aspecto, Novaes (1997, p. 52) coloca uma questão importante: o medo, em determinada época, foi um elemento fundamental na interiorização da dominação nas relações de morada. Durante as Ligas, vivenciaram coletivamente a experiência de perder o medo: "para ser camponês, era preciso, sobretudo, dissipar o medo, enfrentar os conflitos, transpor o espaço do poder privado do latifúndio e ocupar espaços públicos: o fórum, a pista (rodovias), a praça, as ruas da capital”.

Através das lembranças, percebemos que, tanto durante as Ligas quanto durante o conflito, afirmar que o outro está com medo, duvidar da sua coragem, parece ter sido usado como desafio - estratégia de pressão para o engajamento na luta. A coragem, portanto, é um valor moral muito forte para esses camponeses. Sendo assim, não tiveram medo, e sim, receio, como relembra Dona S.:

Às vezes, assim, eu tinha medo, não sabe? Porque muitas vezes os homens [capangas] chegaram lá em casa [...] de noite, atrás de J... [marido], chamando ele, mas eu nunca pensei em desistir não.

P: Tinha medo, mas nunca pensou em desistir?

Não! Tinha receio! (enfático) E quem que não tinha, né? (Dona S.).

A narradora lembra que teve medo, mas, logo em seguida, minimiza-o dizendo que tinha receio, portanto foi corajosa. Por outro lado, se Dona S. sentiu receio, todos também o sentiram. Assim, tendo em vista a violência a que estavam sujeitos, reitera que o seu receio era legítimo. Esse trecho da narrativa nos faz lembrar Riobaldo, do "Grande Sertão: Veredas", quando declara: "Me fez um receio, mas só no bobo do corpo, não no interno das coragens." (GUIMARÃES ROSA, 1986, p. 11).

\section{Uma luta ABençoada por Deus}

Outro aspecto importante é o significado que a luta assume como sendo abençoada por Deus, já que, dentre outros aspectos, não houve mortes.

Mas, graças a Deus só chegou o ponto de apanharem, né? [...] Só foi espancamento, mas, graças a Deus, num morreu nenhum; num houve morte aqui não, graças a Deus não. "Lutemo", "lutemo", "lutemo", mas não chegamos ao 
ponto de nós ofender nenhum dos companheiro, de matar, né? Mas, a aflição, a função deles era de matar a gente, mas, graças a Deus, num chegou esse ponto não, é. Agora "tá" uma beleza, graças a Deus, todo mundo satisfeito, é, podendo trabalhar, né? (Sr. Lo.)

Na perspectiva com a qual trabalhamos, o conceito de memória nos leva à compreensão de que jamais saberemos realmente o que motivou esses camponeses a persistirem na luta. O que temos são as lembranças, resultado de um processo de recriação do passado, no qual os pequenos produtores construíram um discurso numa situação de entrevista, com todas as implicações daí decorrentes. Não perdendo de vista essa perspectiva, cumpre acrescentar que nessas lembranças a bênção de Deus, sobretudo com o apoio e proteção da Igreja, parece ter sido fundamental para que não desistissem. E, nesse sentido, ao se referir ao papel do advogado durante as prisões, Dona L. sugere, em um trecho de seu relato, a relevância da presença dos mediadores nesse processo.

A imagem que constroem é de pessoas que protegeram e foram protegidas. E além da proteção dada aos mediadores, os pequenos produtores de Camucim também relembram que davam coragem a eles. corajoso:

E, assim, há também os que se referem à fé como um dos critérios para ser

P (Pesquisadora): Por que a senhora acha, Dona J...., que teve gente que desistiu da luta e foi embora?

Eu acho que porque não teve coragem, não teve coragem, se assombrou-se e teve medo. (pausa) Aqueles que ficou foi o corajoso. Porque teve muita fé no Divino Espírito Santo, não teve medo nem da morte. Aquele que não tinha fé... era pouca fé, desistiu. Fé não é pra todo mundo. "Ah, eu tinha fé no Divino Espírito Santo!” Mas não é assim! Só dizendo da boca? Está fazendo nada. É ter aquela fé purificada que está no coração. Como essa luta foi vencida debaixo do poder divino. Ela não foi vencida por brincadeira, foi vencida pela uma verdade, e um pedido a Nosso Senhor Jesus Cristo pra vencer essa luta. (Dona Ju).

Dona Ju relaciona a coragem dos camponeses à fé que tinham. Esse tipo de argumentação também aparece em outros discursos. Entretanto, ressalta-se também, em outra entrevista, que a coragem tanto vinha de Deus quanto da própria necessidade de sobrevivência e da falta de perspectiva de uma alternativa para sustentar os filhos.

Há também os que afirmam que essa coragem era resultante do próprio processo de luta, da certeza de que eles, unidos, enfrentando, reagindo, estando dispostos a tudo pela terra, seriam capazes de conter os desmandos da Destilaria. 
Cumpre lembrar que há aqueles que reconhecem que, em determinado momento, pensaram em desistir, mas, por motivos variados (compromisso com os companheiros; importância da existência da pequena produção para abastecer as cidades; consciência; indenização irrisória; Deus não ter deixado), não o fizeram. Não podemos desconsiderar que as lembranças são recriadas a partir do presente. $\mathrm{O}$ fato de terem conquistado a terra e, portanto, segundo eles mesmos, serem vitoriosos, pode condicionar a explicação dos motivos que os levaram a lutar.

Sei que esses cara que judiou com a gente já está aqui embaixo. (pausa) E Camucim ganhou, ganhou em primeiro lugar. E isso o povo sai avançando, pra tomar as terrinha, pra trabalhar e toma. (Sr. R.)

A importância da luta de Camucim é enaltecida pelos narradores devido a sua capacidade de organização, união, coragem, confronto direto com o poder instituído e por ser responsável pelo surgimento de outros assentamentos.

É possível que haja uma idealização do grupo em relação ao movimento. A valorização do sofrimento não afeta essa idealização, uma vez que não podemos desconsiderar a dimensão que o mesmo ocupa na visão de mundo camponesa. Como sugerem os relatos, sem o sacrifício, não existe vida, já que não existe trabalho. É através do sofrimento que "se alcança o Reino dos Céus", portanto ele não se contrapõe a essa suposta idealização da luta de Camucim. É parte imprescindível dela.

Outro aspecto importante é que, apesar de se sentirem vitoriosos, há os que não estão satisfeitos com a situação atual, seja por problemas pessoais com outros assentados, seja por insatisfação com a própria demarcação. No entanto, não se dizem dispostos a enfrentar uma outra luta, apesar de existirem diversos problemas no assentamento. Há quem afirme, porém, que a luta não parou, pelo fato de terem de ajudar outras áreas de conflito, e não, pela necessidade de se organizarem para resolver os próprios problemas. Isso, a nosso ver, não anula os efeitos políticos positivos advindos da experiência de luta e de resistência.

\section{CONSIDERAÇões FINAIS}

Nossa intenção, com essa análise, voltada para o sentido subjetivo que os pequenos produtores que participaram de um conflito de terra atribuem hoje à participação nesse movimento e ao próprio movimento, é contribuir com dados que consideramos preciosos para as discussões travadas sobre a construção das memórias em relatos de história de vida.

Há que desenvolver estudos voltados ao significado que os camponeses dão a essas lutas, significados que se podem captar muito tempo depois, através de uma memória que continuamente se reconstrói. Obviamente, aquilo que está registrado nos documentos deve ser considerado, embora também mereça reparos. Mas quando os sujeitos refletem sobre o passado e reconstroem a memória de eventos importantes para o grupo, importa mais compreendê-los do que confrontar seus testemunhos com a História Oficial. 
E compreender - neste caso, o camponês - é perceber sua ética, seus valores, seus esquecimentos e suas reminiscências, num quadro de referência comum que garante a identidade do grupo e a manutenção de um sentido para suas vidas.

O mais fascinante, porém, nesses episódios de luta, está na vitória (o que contraria modelos prevalecentes em relação ao campesinato) e na consciência da História, o que aparece nas referências às Ligas Camponesas dos anos 50. Ou seja, memórias dentro das memórias, desvelando para o pesquisador um "fio" inesperado da História.

\section{Notas}

${ }^{1}$ A estrutura produtiva da microrregião caracterizava-se, até 1975, pela predominância da policultura alimentar, associada em geral à produção do coco de praia. Nas últimas décadas, a microrregião sofreu forte avanço da plantação de cana-de-açúcar nas áreas de mata, tabuleiro e sobre as lavouras de subsistência (MOREIRA, 1988).

${ }^{2}$ Morador de condição: aquele que tinha a obrigação de trabalhar para a propriedade em troca de um local para morar. Além de trabalhar dois ou três dias gratuitamente (o cambão), dava outros dias de trabalho que podiam ser remunerados. Havia os moradores de condição com sítio (área de terra da propriedade onde os moradores podiam desenvolver uma agricultura de subsistência) e os moradores de condição sem sítio (PALMEIRA, 1976).

${ }^{3}$ A empresa pertence ao Grupo Empresarial Lundgren S.A. Esse grupo tem empresas em vários setores: agropecuário, de tecidos, comércio, hotelaria e finanças e é considerado um dos mais tradicionais da economia brasileira.

${ }^{4} \mathrm{O}$ assentamento dista $75 \mathrm{Km}$ da capital do estado e $5 \mathrm{~km}$ da sede do município de Pitimbu, ao qual pertence. Localiza-se a noroeste deste, estendendo-se sobre um esporão de tabuleiro e sobre a várzea do rio Abiaí. Estão assentadas 37 famílias, embora residam no Assentamento cerca de 72 (dados de 2001). O tamanho dos lotes varia de 0,5 a 12 ha e, além de cultivar a terra, os assentados criam alguns animais (aves, bovinos e caprinos) e pescam na baía do rio Abiaí.

${ }^{5}$ As Ligas Camponesas constituíram importante movimento social rural, marco na organização e luta camponesa nordestina. Surgiram no contexto das mudanças estruturais no setor canavieiro, na década de 50, que resultaram na expropriação e expulsão de camponeses das propriedades. Para maiores detalhes, consulte Azevedo (1982), Bastos (1984), Benevides (1985).

${ }^{6}$ Para a análise das entrevistas, recorremos à proposta de Análise de Discurso sugerida por Carmo (1997).

${ }^{7}$ Segundo versão encontrada no texto dos pesquisadores do Núcleo de Documentação e Informação Histórica Regional (1992), o proprietário morreu em 1975, e os herdeiros que moravam em Recife e em Goiás assumiram a administração da fazenda. Os pequenos produtores passaram a pagar a renda da terra em forma de aforamento (aluguel anual pago em dinheiro).

${ }^{8}$ Informações obtidas junto aos funcionários do INCRA - João Pessoa/ PB, 1996.

${ }^{9}$ Vale salientar que, entre os inúmeros acontecimentos, o vigário da paróquia foi ameaçado, e o arcebispo da capital, por ocasião da proibição da entrada de "pessoas estranhas" em Camucim, foi proibido de rezar missa (realizando a missa na estrada).

\section{REFERÊNCIAS}

ANNI, R. et al. I gesti e i sentimenti: le donne nella resistenza bresciana, percorsi di lettura. Brescia: Tipolitografia Queriniana, 1990.

AZEVEDO, F. A. As ligas camponesas. Rio de Janeiro: Paz e Terra, 1982.

BASTOS, E. R. As ligas camponesas. Petrópolis: Vozes, 1984.

BENEVIDES, C. Camponeses em marcha. Rio de Janeiro: Paz e Terra, 1985.

Fractal, Rev. Psicol., v. 25 - n. 1, p. 23-40, Jan./Abr. 2013 
BOSI, E. Memória e Sociedade: lembranças de velhos. 7. ed. São Paulo: EDUSP, 1994.

CARMO, S. I. S. Discurso, sociedade e história. Araraquara, 1997. Mimeografado.

CIAMPA, A. C. A estória de Severino e a história de Severina: um ensaio de Psicologia social. São Paulo: Brasiliense, 1987.

GUIMARÃES ROSA, J. Grande sertão: veredas. 37. ed. Rio de Janeiro: Nova Fronteira, 1986.

MOREIRA, E. Mesorregiões e microrregiões da Paraíba: delimitação e caracterização. João Pessoa: GAPLAN, 1988.

MOREIRA, E; TARGINO, I. Capitulos de geografia agrária da Paraíba. João Pessoa: Universitária/UFPB, 1997.

NOVAES, R R. De corpo e alma: catolicismo, classes sociais e conflitos no campo. Rio de Janeiro: Graphia, 1997.

NÚCLEO DE DOCUMENTAÇÃO E INFORMAÇÃO HISTÓRICA REGIONAL. Ficha de levantamento do conflito de Camucim. João Pessoa, Fundo Comissão Pastoral da Terra (CPT)/Arquivo Eclesiástico da Paraíba, 1992. Mimeografado.

PALMEIRA, M. Casa e trabalho: notas sobre as relações sociais na plantation tradicional. Paris, 1976. Mimeografado. Apresentado como comunicação no Simpósio "Le rapport au travail dans les sociétes américaines", Congresso dos Americanistas.

PASSERINI, L. Sette punti sulla memoria per l'interpretazione delle fonti orali. Italia Contemporanea, Genova, fasc. 143, p. 83-92, 1981.

POLLAK, M. Memória, esquecimento, silêncio. Estudos Históricos, Rio de Janeiro, v. 2, n. 3, p. 3-15, 1989.

PORTELLI, A. O que faz a história oral diferente. Projeto História, São Paulo, n. 14, p 25-39, 1997.

PORTELLI, A. Intervistare il movimento: il '68 e la storia orale. I Giorni Cantati, Roma, anno III, n. 9, p. 27-32, 1989.

PORTELLI, A. Problemi di metodo: sulla diversità della storia orale. In: BERMANI, C. (a cura). Introduzione alla storia orale: storia, conservazione delle fonti e problemi di metodo. Roma: Odradek, v. I, 1999. p. 149-166. 
PORTELLI, A. Le Fosse Ardeatine e la memoria: rapporto su un lavoro in corso. In: PAGGI, L. (a cura). Le memorie della Repubblica. Milano: Il Saggiatore, 2000a. p. 89-154.

PORTELLI, A. Non s'è presentato nessuno: i due giorni dei deportati ebrei romani al Collegio Militare di Piazza della Rovere. In: PROSPERI, A. (a cura). Roma: la città dei papi. Torino: Einaudi, 2000b. p. 585-604.

QUEIROZ, M. I. P. Relatos orais: do "indizível” ao "dizível”. In: VON SIMSON, M.O. Experimentos com histórias de vida (Itália-Brasil). São Paulo: Revista dos Tribunais Ltda, 1988. p.14-43.

SCOTT, J. I contadini tra sopravvivenza e rivolta. Napoli: Liguori, 1981.

SILVEIRA BUENO, F. Minidicionário da Lingua Portuguesa. 3. ed. São Paulo: Lisa, 1989.

WHITAKER, D. C. A et al. A transcrição da fala do homem rural: fidelidade ou caricatura? In: WHITAKER, D. C. A. (Org.) Sociologia Rural: questões metodológicas emergentes. Presidente Venceslau, SP: Letras à Margem, 2002. p. $115-120$.

WOORTMANN, E.; WOORTMANN, K. O trabalho da terra: a lógica e a simbólica da lavoura camponesa. Brasília: UnB, 1997.

Recebido em: 29 de agosto de 2010 Aceito em: 05 de setembro de 2012 
